\title{
Clevudine Is Highly Efficacious in Hepatitis B e Antigen-Negative Chronic Hepatitis B with Durable Off-Therapy Viral Suppression
}

\author{
Byung Chul Yoo, ${ }^{1}$ Ju Hyun Kim, ${ }^{2}$ Tae-Hun Kim, ${ }^{3}$ Kwang Cheol Koh, ${ }^{1}$ Soon-Ho Um, ${ }^{4}$ Young Soo Kim, ${ }^{5}$ Kwan Sik Lee, ${ }^{6}$ \\ Byung Hoon Han, ${ }^{7}$ Chae Yoon Chon, ${ }^{6}$ Joon-Yeol Han, ${ }^{8}$ Soo Hyung Ryu, ${ }^{9}$ Haak Cheoul Kim, ${ }^{10}$ Kwan Soo Byun, ${ }^{4}$ \\ Seong Gyu Hwang, ${ }^{11}$ Byung-Ik Kim, ${ }^{12}$ Mong Cho, ${ }^{13}$ Kwon Yoo, ${ }^{3}$ Heon-Ju Lee, ${ }^{14}$ Jae Seok Hwang, ${ }^{15}$ Yun Soo Kim, ${ }^{2}$ \\ Young-Suk Lee, ${ }^{8}$ Sung-Kyu Choi, ${ }^{16}$ Youn-Jae Lee, ${ }^{17}$ Jin-Mo Yang, ${ }^{8}$ Joong-Won Park, ${ }^{18}$ Myung-Seok Lee, ${ }^{19}$ \\ Dae-Ghon Kim, ${ }^{20}$ Young-Hwa Chung, ${ }^{21}$ Se-Hyun Cho,${ }^{8}$ Jong-Young Choi, ${ }^{8}$ Young-Oh Kweon, ${ }^{22}$ Heon Young Lee, ${ }^{23}$ \\ Sook-Hyang Jeong, ${ }^{24}$ Hee-Won Yoo, ${ }^{25}$ and Hyo-Suk Lee ${ }^{26}$
}

\begin{abstract}
Clevudine is a pyrimidine analog with potent and sustained antiviral activity against HBV. In the present study, we evaluated the safety and efficacy of clevudine $30 \mathrm{mg}$ daily for 24 weeks and assessed the durability of antiviral response for 24 weeks after cessation of dosing in hepatitis $\mathrm{B}$ e antigen ( $\mathrm{HBeAg}$ )-negative chronic hepatitis $\mathrm{B}$ (e-CHB). We randomized a total of 86 patients (3:1) to receive clevudine $30 \mathrm{mg}(\mathrm{n}=63)$ or placebo $(\mathrm{n}=23)$ daily for 24 weeks. We followed patients for an additional 24 weeks after withdrawal of treatment. The median changes in HBV DNA from baseline were -4.25 and $-0.48 \log _{10}$ copies $/ \mathrm{mL}$ at week 24 in the clevudine and placebo groups, respectively $(P<0.0001)$. Viral suppression in the clevudine group was sustained after withdrawal of therapy, with $3.11 \log _{10}$ reduction at week 48. At week 24 and week $48,92.1 \%$ and $16.4 \%$ of patients in the clevudine group had undetectable serum HBV DNA levels by Amplicor PCR assay ( $<300$ copies $/ \mathrm{mL}$ ). The proportion of patients who achieved ALT normalization was $74.6 \%$ and $33.3 \%$ in the clevudine and placebo groups at week 24 , respectively $(P=0.0006)$. ALT normalization in the clevudine group was well-maintained during the post-treatment follow-up period. The incidence of adverse events was similar in the 2 groups. No resistance to clevudine was detected during treatment. Conclusion: A 24-week clevudine therapy was well-tolerated and showed potent and sustained antiviral effect without evidence of viral resistance in e-CHB patients. However, treatment for longer than 24 weeks would be needed to achieve durable remission. (HePATOLOGY 2007;46:1041-1048.)
\end{abstract}

\footnotetext{
Abbreviations: HBeAg, hepatitis B e antigen; e-CHB, HBeAg-negative chronic hepatitis B; ULN, upper limit of normal; LOD, limit of detection From the ${ }^{1}$ Sungkyunkwan University Samsung Medical Center, Seoul, South Korea; ${ }^{2}$ Gachon Medical School; ${ }^{3}$ Ewha Womans University; ${ }^{4}$ Korea University Hospital; ${ }^{5}$ Inha University Hospital; ${ }^{6}$ Yonsei University Hospital; ${ }^{7}$ Kosin Medical School; ${ }^{8}$ The Catholic University of Korea; ${ }^{9}$ Inje University Seoul Paik Hospital; ${ }^{10}$ Wonkwang University Hospital; ${ }^{11}$ Pochon CHA University Bundang CHA Hospital; ${ }^{12}$ Kangbuk Samsung Medical Center; ${ }^{13}$ Pusan National University Hospital; ${ }^{14}$ Youngnam University Medical Center; ${ }^{15}$ Keimyung University Dongsan Medical Center; ${ }^{16}$ Chonnam National University Hospital; ${ }^{77}$ Inje University Busan Paik Hospital; ${ }^{18}$ National Cancer Center; ${ }^{19}$ Hallym University Medical Center Kangnam Sacred Heart Hospital; ${ }^{20}$ Chonbuk National University Hospital; ${ }^{21}$ Asan Medical Center; ${ }^{22}$ Kyungpook National University Hospital; ${ }^{23}$ Chungnam National University Hospital; ${ }^{24}$ Korea Institute of Radiological and Medical Sciences; ${ }^{25}$ Bukwang Pharmaceutical Co., Ltd.; ${ }^{26}$ Seoul National University Hospital, Seoul, South Korea.

Received January 11, 2007; accepted April 10, 2007.

Supported by the Bukwang Pharmaceutical Co. Ltd. and in part by the Korea Health 21 R\&D Project, Ministry of Health \& Welfare, Republic of Korea (Grant No. 02-PJ2-PG4-PT01-0034)

NIH clinical trial registration number: NCT00313274.

Address reprint requests to: Hyo-Suk Lee, M.D., Department of Internal Medicine and Liver Research Institute, Seoul National University College of Medicine, 28

Yungun-dong, Chongno-gu, Seoul 110-744, Korea. E-mail: hsleemd@snu.ac.kr; fax: 82-2-744-8243.

Copyright (C) 2007 by the American Association for the Study of Liver Diseases.

Published online in Wiley InterScience (www.interscience.wiley.com).

DOI 10.1002/hep.21800

Potential conflict of interest: Nothing to report.
} 
$\mathrm{H}$ epatitis B virus (HBV) infection is a major global health problem. More than 350 million people in the world are chronically infected and 500,000 to 1.2 million deaths per year are attributed to $\mathrm{HBV}$-associated complications. ${ }^{1,2}$

Hepatitis $\mathrm{B}$ e antigen ( $\mathrm{HBeAg}$ )-negative chronic hepatitis $\mathrm{B}$ (e-CHB) occurs in patients who are negative for $\mathrm{HBeAg}$ and positive for antibodies against $\mathrm{HBeAg}$ and in whom serum HBV DNA and ALT levels remain persistently or intermittently elevated. ${ }^{3-5}$ The median prevalence of e-CHB in hepatitis $\mathrm{B}$ surface antigen-positive carriers was reported to be $33 \%$ in the Mediterranean region, $15 \%$ in Asia Pacific, and $14 \%$ in the United States and Northern Europe. ${ }^{5}$

e-CHB is caused by HBV variants with mutations in the precore or core promoter regions of the viral genome, which reduce or prevent synthesis of the HBeAg. It has been suggested that the variants have an immunologic advantage over wild-type HBV. ${ }^{3,4}$ However, e-CHB is a heterogeneous condition and wild-type HBV may also be responsible for disease activity in some patients. ${ }^{6}$ In Korean patients infected with $\mathrm{HBV}$ genotype $\mathrm{C}$, precore mutation and core promoter mutation was almost invariably associated with e-CHB. ${ }^{7}$ The clinical profile of e$\mathrm{CHB}$ differs from that of $\mathrm{HBeAg}$-positive disease in that patients are typically older, ${ }^{4}$ serum HBV DNA levels are lower, ${ }^{8,9}$ liver disease tends to be more advanced, ${ }^{10-12}$ and the likelihood of spontaneous remission is very low. ${ }^{4,11}$

The endpoint of treatment for HBeAg-negative chronic hepatitis B is not established. HBeAg loss or seroconversion cannot be used to define response and treatment usually focuses on suppression of HBV DNA and normalization of ALT levels. ${ }^{13}$ Recently, several studies have shown that effective suppression of HBV DNA in $\mathrm{e}-\mathrm{CHB}$ is associated with histologic improvement in the liver and long-term clinical benefit. ${ }^{14-16}$ Therefore, treatment guidelines support the use of conventional or pegylated interferon, lamivudine, adefovir, entecavir, or telbivudine for e-CHB in patients with viremia and elevated ALT levels. ${ }^{17-20}$ However, optimal treatment for patients with e-CHB remains to be defined. Pegylated interferon alpha in e-CHB demonstrated limited efficacy, with $19 \%$ of sustained viral suppression and an adverseevent profile similar to that of interferon alpha. ${ }^{21}$ One year of treatment of patients with e-CHB with lamivudine produced histologic improvement in $60 \%$ of patients but with high resistance rates of up to $27 \% .^{22}$ Treatment of e-CHB with adefovir for 1 year resulted in histologic improvement in $64 \%$ and normalization of the ALT level in $72 \%$ of patients, with no evidence of resistance. ${ }^{23}$ However, resistance to adefovir developed in $28 \%$ of $\mathrm{HBeAg}$-negative patients after 5 years of treat- ment. ${ }^{24}$ Entecavir has been shown to be superior to lamivudine in virologic, biochemical, and histologic improvement. ${ }^{25}$ Resistance to entecavir has been shown to develop in $0.7 \%(1 / 143)$ of nucleoside-naive patients and $15 \%$ to $19 \%$ of lamivudine-refractory patients after 3 years of treatment. ${ }^{26}$ As currently approved antiviral agents for chronic $\mathrm{HBV}$ infection do not provide a cure or durable remission in the majority of patients, there remains a need for a regimen that is safe and effective, with potent and sustained viral suppression while the development of resistant mutants is minimized.

Clevudine [1-(2-deoxy-2-fluoro- $\beta$-L-arabinofuranosyl) thymine, L-FMAU] is a nucleoside analog of the unnatural $\beta$-L configuration that has potent activity against $\mathrm{HBV}$ and some activity against Epstein-Barr virus in vitro. ${ }^{27-29}$ The lack of cytotoxicity reflects the inability of human cellular DNA polymerases $\alpha, \beta, \gamma$, and $\delta$ to utilize the $5^{\prime}$-triphosphate of clevudine as a substrate. ${ }^{30,31}$ Moreover, clevudine was found to have no effect on mitochondrial structure, DNA content, or function. ${ }^{30,31}$ A uniquely advantageous characteristic of clevudine is prolonged suppression of viral replication even after withdrawal of treatment. In woodchucks infected with woodchuck hepatitis virus, clevudine $10 \mathrm{mg} / \mathrm{kg}$ for 4 weeks led to prompt and profound viral suppression with up to $8 \log _{10}$ reduction of plasma woodchuck hepatitis virus DNA, which was sustained for more than 12 weeks after cessation of dosing. ${ }^{32}$ The sustained viral suppression has been demonstrated to be associated with significant reduction of covalently closed circular DNA in hepatocytes. ${ }^{33,34}$

In previous clinical trials, clevudine was safe and showed potent and durable antiviral activity without evidence of viral resistance in $\mathrm{HBeAg}$-positive chronic hepatitis B. ${ }^{35-37}$ We conducted the present study to evaluate the safety and efficacy of $30 \mathrm{mg}$ clevudine once a day for 24 weeks and to assess the durability of antiviral response for 24 weeks after cessation of therapy in e-CHB.

\section{Patients and Methods}

Study Design. We conducted this double-blind, randomized, placebo-controlled, phase III study at 31 centers in South Korea. We randomized patients (based on a predetermined computer-generated list) to receive clevudine $30 \mathrm{mg}$ or placebo once a day for 24 weeks. After completion of therapy, we followed patients for an additional 24 weeks.

We obtained written informed consent, as approved by the Ethics Committees and the Korean Food and Drug Administration, from all subjects. We conducted the study under the ICH/Good Clinical Practice (GCP) 
guidelines and in accordance with the principles of the Declaration of Helsinki.

We evaluated patients at baseline and monitored them on days 8,15 , and 29 and every 4 weeks thereafter during the dosing period. After 24 weeks of therapy, we followed patients at weeks 28, 34, 40, and 48. Monitoring of patients consisted of open-ended interviews for tolerability, physical examination, electrocardiography, and laboratory assessment, including serum HBV DNA levels.

Study Population. Eligible patients were adults of 18 to 60 years in age with $\mathrm{HBeAg-negative} \mathrm{chronic} \mathrm{hepatitis}$ $\mathrm{B}$, as defined by the presence in serum of hepatitis $\mathrm{B}$ surface antigen for more than 6 months, negative for $\mathrm{HBeAg}$ and positive for antibodies against $\mathrm{HBeAg}$, and HBV DNA levels $\geq 1 \times 10^{5}$ copies $/ \mathrm{mL}$. Eligible patients also had serum ALT levels between 1.2 and 15 times the upper limit of normal (ULN). Exclusion criteria included coinfection with hepatitis $\mathrm{C}$, hepatitis $\mathrm{D}$, or HIV; evidence of cirrhosis or hepatocellular carcinoma; previous exposure to any nucleoside analog that is active against $\mathrm{HBV}$; and use of interferon alpha within 6 months before enrollment. We also excluded breastfeeding or pregnant women or women of childbearing age unwilling to use barrier contraceptive methods.

We calculated the sample size to detect a minimum of $50 \%$ of difference in the proportion of patients with serum HBV DNA below 4700 copies $/ \mathrm{mL}$ at the end of treatment (24 weeks) between clevudine and placebo. We anticipated that placebo response would be $20 \%$ and that for clevudine $70 \%$. We estimated the sample size using the Z-test with an alpha level of 0.05 and $95 \%$ power for comparing the placebo group with the clevudine group. The ratio of patient numbers in each group (placebo, clevudine $30 \mathrm{mg}$ ) was $1: 3$. According to this calculation, we calculated 45 patients of the clevudine group and 15 patients of the placebo group (a total of 60 patients), and we enrolled a total of 86 patients to allow for subject dropout.

Efficacy Endpoints. The primary efficacy end point was reduction in serum HBV DNA, defined as median $\log _{10}$ decrease from baseline at the end of treatment and during the follow-up period after withdrawal of treatment. We measured serum HBV DNA levels at a central laboratory using the Digene Hybrid Capture II assay (Digene Corp., Gaithersburg, MD) with a lower limit of detection (LOD) of 4700 copies/mL. When HBV DNA was undetectable by the Digene Hybrid Capture II assay, we used the COBAS Amplicor PCR assay (Roche Molecular Systems, Branchburg, NJ) with a lower LOD of 300 copies/mL to measure lower levels of HBV DNA.

Secondary end points included the proportion of patients with undetectable HBV DNA, as measured by the
COBAS Amplicor PCR assay, and normalization of serum ALT.

Safety Analysis. The safety analysis included data from all 86 eligible patients who received at least 1 dose of study medication after randomization. Safety evaluations included analysis of adverse events, serious adverse events, and deaths. We defined exacerbation of hepatitis B as ALT and/or AST elevations: (1) $>20 \times$ ULN or (2) $>10 \times$ ULN and a 10-fold change from the lowest onstudy value. We considered exacerbation of hepatitis B as a serious adverse event.

Genotypic Analysis. We performed genotypic analysis of the HBV DNA polymerase domain (amino acids 119 to 247) by dideoxy sequencing at baseline and at the end of the 24-week dosing period. For detection of lamivudine-related YMDD (Tyrosine-Methionine-AsparateAspartate) mutations at rt180 and rt204, we performed an RFLP (Restriction Fragment Length Polymorphism) assay at baseline and at the end of the 24-week dosing period, according to methods described. ${ }^{31}$ We defined HBV DNA breakthrough as an increase in the level of HBV DNA of at least $1 \log _{10}$ copies/mL from the lowest point while on treatment.

Statistical Analysis. We analyzed results on the basis of intention-to treat. We included all 86 eligible patients who received at least 1 dose of the study medication after randomization in the safety analysis. We included patients discontinuing the study after receiving the first study drug dose in the efficacy analysis until the time of their discontinuation.

We assessed the overall treatment comparison using the Wilcoxon test for continuous data, and the chisquared test or a 2-sided Fisher's exact test for categorical data. We performed statistical significance with an alpha level of 0.05 .

\section{Results}

Study Population. We enrolled a total of 86 eligible patients at 31 sites between July 29, 2003 and January 15, 2004; they received at least 1 dose of clevudine $30 \mathrm{mg}$ $(n=63)$ or placebo $(n=23)$ in a blinded fashion. The 2 treatment groups were well-balanced at baseline (Table 1).

Out of the 86 patients, 82 (61 in the clevudine group and 21 in the placebo group) completed the 48-week study. Four patients withdrew from the study: 2 patients in the placebo group during treatment period and $2 \mathrm{pa}-$ tients in the clevudine group during the follow-up period (Fig. 1).

Virologic and Serologic Endpoints. Table 2 summarizes the serum HBV DNA response in the 2 groups. 
Table 1. Patient Characteristics at Baseline

\begin{tabular}{|c|c|c|c|c|}
\hline & Clevudine $(n=63)$ & Placebo $(n=23)$ & Total $(n=86)$ & $P$ value \\
\hline Gender & & & & $0.7556 *$ \\
\hline Male (n, \%) & $52(82.5)$ & $18(78.3)$ & $70(81.4)$ & \\
\hline Female (n, \%) & $11(17.5)$ & $5(21.7)$ & $16(18.6)$ & \\
\hline Median Age (years) & 44 & 41 & 42.5 & $0.5878^{\dagger}$ \\
\hline Median Serum HBV DNA ( $\log _{10}$ copies/mL) & 6.92 & 6.37 & 6.73 & $0.1704^{\dagger}$ \\
\hline Median ALT (U/L) & 113.0 & 94.0 & 110 & $0.7512^{\dagger}$ \\
\hline Mean ALT (U/L) & 161.4 & 149.6 & 158.3 & $0.6991^{\ddagger}$ \\
\hline ALT & & & & $0.7958^{\S}$ \\
\hline$<2 \times$ ULN at baseline, $\mathrm{n}(\%)$ & $20(31.8)$ & $9(39.1)$ & $29(33.7)$ & \\
\hline $2 \times$ to $<5 \times$ ULN at baseline, $n(\%)$ & $26(41.3)$ & $8(34.8)$ & $34(39.5)$ & \\
\hline$\geq 5 \times$ ULN at baseline, $n(\%)$ & $17(27.0)$ & $6(26.1)$ & $23(26.7)$ & \\
\hline
\end{tabular}

*Two-sided Fisher’s exact test. ${ }^{\dagger}$ Wilcoxon rank-sum test. ${ }^{\ddagger} t$ test, ${ }^{\S}$ Chi-squared test.

Clevudine treatment for 24 weeks produced prompt and profound viral suppression. Median serum HBV DNA reduction from baseline at week 24 was 4.25 and 0.48 $\log _{10}$ copies $/ \mathrm{mL}$ in the clevudine and placebo groups, respectively $(P<0.0001)$. Viral suppression in the clevudine group was sustained even after withdrawal of treatment with $3.11 \log _{10}$ reduction at week 48 , compared with $0.66 \log _{10}$ reduction at week 48 in the placebo group $(P<0.0001)$ (Fig. 2$)$.

At the end of treatment for 24 weeks, the majority of patients $(92.1 \%)$ in the clevudine group but none of 21 patients in the placebo group had undetectable serum HBV DNA levels by the Amplicor PCR assay (less than 300 copies $/ \mathrm{mL})(P<0.0001)$. The proportion of patients with viral loads below the LOD after withdrawal of therapy was significantly higher in the clevudine group than in the placebo group: $80.3 \%$ versus $19.1 \%$ by Digene $\mathrm{Hy}$ brid Capture II and $47.5 \%$ versus $4.8 \%$ by Amplicor PCR at week 34; 67.2\% versus $23.8 \%$ by Digene Hybrid Capture II and $16.4 \%$ versus $0 \%$ by Amplicor PCR at week 48 , in the clevudine and placebo groups, respectively.

Biochemical Endpoints. The proportion of patients who achieved normalization of ALT levels was $74.6 \%$ in

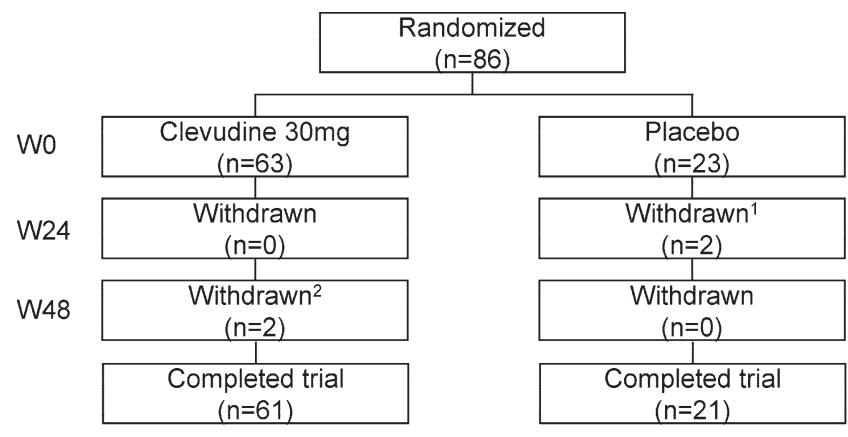

1 Two patients due to consent withdrawal

2 Two patients due to consent withdrawal

Fig. 1. Flow chart of the present study. the clevudine group and $33.3 \%$ in the placebo group at week $24(P=0.0006)$. In accordance with prolonged viral suppression, ALT normalization in the clevudine group was well-maintained during the post-treatment follow-up period. The ALT normalization rates in the clevudine group increased further after withdrawal of therapy up to $86.7 \%$ at week 34 and then decreased to $70.5 \%$ at week 48 ; these proportions were significantly higher than in the placebo group (Fig. 3).

Genotypic Analysis. Comparative analysis of the genomic sequence of HBV isolated from the serum of patients at baseline and at the end of the 24-week dosing period revealed no emerging substitutions in conserved sites of the polymerase. We did not detect Lamivudinerelated YMDD mutations at $\mathrm{rt} 180$ and $\mathrm{rt} 204$ by the RFLP assay at baseline and at the end of the 24-week dosing period in either group.

Effect of Pretreatment ALT Levels on Viral Response. To evaluate the efficacy according to baseline ALT levels, we stratified the patients into 3 subgroups of ALT $<2 \times$ ULN, ALT $\geq 2 \times$ to $<5 \times$ ULN, and ALT $\geq 5 \times$ ULN. There was no significant difference in the proportion of patients with HBV DNA below 4700 copies/mL among the clevudine subgroups at week 24, week 34, and week 48, respectively (Table 3 ).

Safety and Tolerability. The median exposure to the study drug was 166 days in the 2 groups, which was close to the intended exposure of 168 days. No discontinuation of treatment occurred due to adverse events in either group.

The cumulative safety data during the treatment period and the post-treatment follow-up period are summarized in Table 4. During the treatment period, the incidence of adverse events and serious adverse events was similar in the 2 groups. The most frequent adverse event in the clevudine group was upper respiratory symptoms (14.3\%) followed by abdominal pain, asthenia, and headache. In the placebo group, the most frequent adverse 
Table 2. Summary of Serum HBV DNA Response

\begin{tabular}{|c|c|c|c|}
\hline & Clevudine $(n=63)$ & Placebo $(n=23)$ & $P$ value \\
\hline Median $\log _{10} \mathrm{HBV}$ DNA at Baseline & 6.92 & 6.37 & $0.1704^{*}$ \\
\hline \multicolumn{4}{|c|}{ Median Change in HBV DNA ( $\log _{10}$ copies $/ \mathrm{mL}$ ) } \\
\hline From Baseline to Week 24 & -4.25 & -0.48 & $<0.0001^{*}$ \\
\hline From Baseline to Week 34 & -3.85 & -0.43 & $<0.0001^{*}$ \\
\hline From Baseline to Week 48 & -3.11 & -0.66 & $<0.0001^{*}$ \\
\hline \multicolumn{4}{|l|}{ HBV DNA $<4700$ copies $/ \mathrm{mL}$} \\
\hline Week $24(\mathrm{n} / \mathrm{N}, \%)$ & $59 / 63(93.7)$ & $3 / 21(14.3)$ & $<0.0001^{\dagger}$ \\
\hline Week 34 (n/N, \%) & 49/61 (80.3) & 4/21 (19.1) & $<0.0001^{\dagger}$ \\
\hline Week $48(\mathrm{n} / \mathrm{N}, \%)$ & $41 / 61(67.2)$ & $5 / 21(23.8)$ & $0.0005^{\dagger}$ \\
\hline \multicolumn{4}{|l|}{ HBV DNA $<300$ copies $/ \mathrm{mL}$} \\
\hline Week $24(\mathrm{n} / \mathrm{N}, \%)$ & $58 / 63(92.1)$ & $0 / 21(0.0)$ & $<0.0001^{\dagger}$ \\
\hline Week 34 (n/N, \%) & $29 / 61(47.5)$ & $1 / 21(4.8)$ & $0.0004^{\dagger}$ \\
\hline Week $48(\mathrm{n} / \mathrm{N}, \%)$ & $10 / 61(16.4)$ & $0 / 21(0.0)$ & $0.0575^{\ddagger}$ \\
\hline
\end{tabular}

*Wilcoxon rank-sum test. ${ }^{\dagger}$ Chi-squared test. ${ }^{\ddagger}$ Two-sided Fisher’s exact test.

events included upper respiratory symptoms (17.4\%), increased ALT (8.7\%), asthenia, and abdominal pain. We observed ALT elevations to a level $\geq 5$ times the ULN significantly less frequently in the clevudine group (4.8\%) than in the placebo group $(21.7 \%)$. We observed exacerbation of hepatitis B during treatment in 1 patient in the clevudine group $(1.6 \%)$ and in 2 patients in the placebo group $(8.7 \%)$. These exacerbations were self-limited, without signs of hepatic decompensation, in spite of continued treatment. During the post-treatment follow-up period, the incidence of adverse events and serious adverse events were similar in the 2 groups. There was no serious adverse event that was considered by the investigators to be definitely related to the study drug.

\section{Discussion}

In this randomized placebo-controlled trial, clevudine $30 \mathrm{mg}$ daily for 24 weeks showed highly potent antiviral activity in patients with e-CHB. Clevudine suppressed HBV DNA by a median of $4.25 \log _{10}$ copies $/ \mathrm{mL}$ and $92.1 \%$ of patients treated with 24 weeks of clevudine had undetectable levels of HBV DNA levels by the PCR assay. Although direct head-to-head comparisons are not avail-

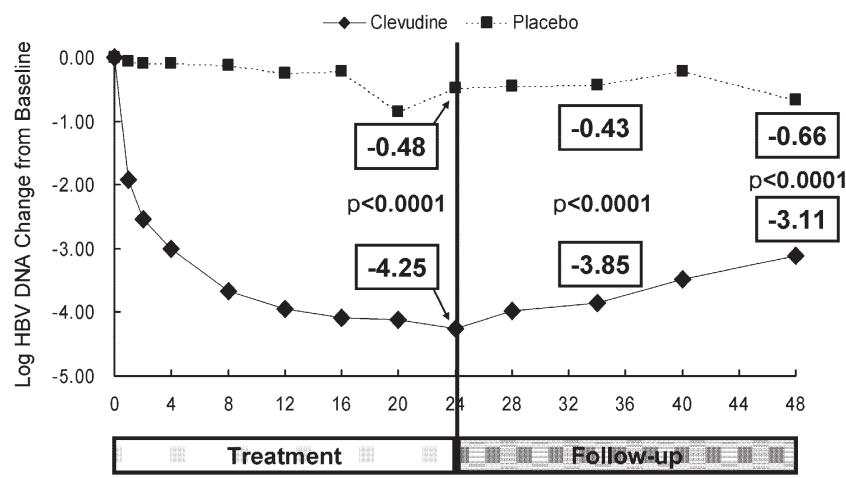

Fig. 2. Median $\log _{10} \mathrm{HBV}$ DNA change from baseline. able, the proportion of patients who had undetectable levels of HBV DNA levels by PCR assay after 24 weeks of clevudine treatment $(92.1 \%)$ appears higher than that achieved by 48 -week treatment with $100 \mathrm{mg}$ of lamivudine once daily $(72 \%)^{25}$ or $10 \mathrm{mg}$ of adefovir dipivoxil once daily (51\%). ${ }^{23}$ Our result is comparable with that of 48 weeks of treatment with $0.5 \mathrm{mg}$ once daily of entecavir $(90 \%) .{ }^{25}$ It is remarkable that the short period of 24 weeks of clevudine treatment demonstrated such a potent antiviral activity.

Current antiviral agents against HBV tend to be more effective in the patients with higher baseline ALT levels than those with lower baseline ALT levels, presumably related to the immune response against HBV. ${ }^{38}$ However, clevudine in this study produced profound viral suppression with prolonged antiviral activity in patients with relatively normal ALT levels at baseline as well as in patients with high ALT levels. These findings suggest that viral suppression by clevudine is independent of the host's immune response against $\mathrm{HBV}$.

In previous clinical trials, ${ }^{35,36}$ clevudine therapy for as short as 4 weeks or 12 weeks showed antiviral activity even after withdrawal of therapy in patients with $\mathrm{HBeAg}$-positive chronic hepatitis B. Sustained antiviral effect after cessation of dosing is a peculiar characteristic of clevudine. Prolonged antiviral therapy has been shown to induce the development of drug-resistant HBV mutants, and the frequency of the development of resistant mutants increases in proportion to the duration of therapy. In the present study, we aimed to determine the minimal duration of therapy to achieve durable remission while avoiding the emergence of resistant mutants. Therefore, we designed the study to assess the durability of viral suppression after a relatively short period of clevudine therapy for 24 weeks. A clinical trial for evaluating longer-term (48- 


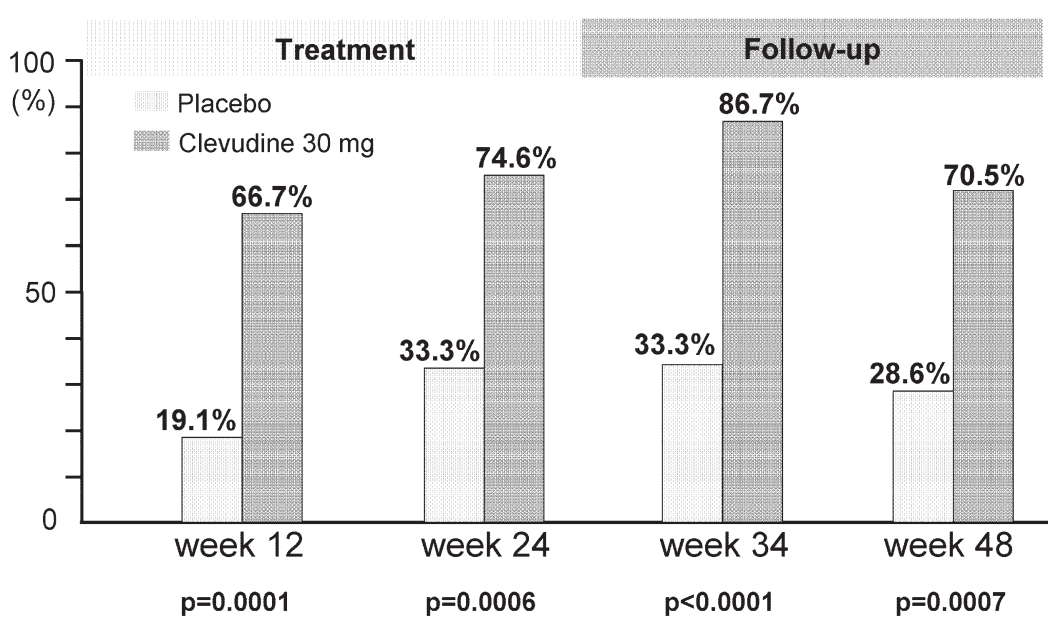

Fig. 3. Changes in the serum ALT normalization rate.

week) safety and efficacy of clevudine therapy is now under way.

The present study had a placebo control arm rather than a treated comparison arm such as lamivudine. At the initiation time of the present clinical trial, lamivudine was the only oral drug that was approved for the treatment of chronic hepatitis B in Korea. However, it was known that untimely withdrawal of lamivudine might deteriorate hepatic function, ${ }^{39}$ and as the study included a follow-up period off-treatment, lamivudine was considered to be inappropriate as a comparison drug. Thus, we selected placebo as a control and all patients enrolled in the present trial who did not achieve virologic and biochemical response at the end of the study were re-enrolled into a 1-year open-label clevudine treatment.

As shown in animal models ${ }^{32-34}$ and in clinical trials for patients with $\mathrm{HBeAg}$-positive chronic hepatitis $\mathrm{B},{ }^{35-37}$ the current study also demonstrated prolonged antiviral ac-

Table 3. Proportion of Patients with HBV DNA Below 4700 copies/mL by Baseline ALT Categories

\begin{tabular}{llll}
\hline & $\begin{array}{c}\text { Clevudine 30 } \\
\text { mg }(\mathbf{n}=\mathbf{6 3})\end{array}$ & $\begin{array}{c}\text { Placebo } \\
(\mathbf{n}=\mathbf{2 3})\end{array}$ & P value* \\
\hline Week 24 (n/N, \%) & & & \\
ALT $<2 \times$ ULN & $19 / 20(95.0)$ & $1 / 8(12.5)$ & $<0.0001$ \\
ALT $\geq 2 \times$ to $<5 \times$ ULN & $24 / 26(92.3)$ & $1 / 8(12.5)$ & $<0.0001$ \\
ALT $\geq 5 \times$ ULN & $16 / 17(94.1)$ & $1 / 5(20.0)$ & 0.0033 \\
Week 34 (n/N, \%) & & & \\
ALT $<2 \times$ ULN & $16 / 20(80.0)$ & $1 / 8(12.5)$ & 0.0019 \\
ALT $\geq 2 \times$ to $<5 \times$ ULN & $19 / 24(79.2)$ & $2 / 8(25.0)$ & 0.0099 \\
ALT $\geq 5 \times$ ULN & $14 / 17(82.4)$ & $1 / 5(20.0)$ & 0.0207 \\
Week 48 (n/N, \%) & & & \\
ALT $<2 \times$ ULN & $13 / 20(65.0)$ & $1 / 8(12.5)$ & 0.0329 \\
ALT $\geq 2 \times$ to $<5 \times$ ULN & $15 / 24(62.5)$ & $2 / 8(25.0)$ & 0.1058 \\
ALT $\geq 5 \times$ ULN & $13 / 17(76.5)$ & $2 / 5(40.0)$ & 0.2743 \\
\hline
\end{tabular}

*Two-sided Fisher's exact test. tivity after withdrawal of treatment in e-CHB. At 24 weeks after discontinuation of clevudine treatment, the median HBV DNA was still $3.11 \log _{10}$ below the baseline level and $67.2 \%$ of patients maintained serum $\mathrm{HBV}$ DNA levels below 4,700 copies $/ \mathrm{mL}$. Although the exact mechanism of this prolonged antiviral effect is still unknown, one plausible explanation may be a reduction of intrahepatic covalently closed circular DNA through elimination of $\mathrm{HBV}$-infected hepatocytes, as observed in woodchucks. ${ }^{33}$

Although the potency and durability acquired by clevudine therapy for 24 weeks were encouraging, 24 weeks of therapy was not sufficient for durable remission. Since only $16.4 \%$ of treated patients were still HBV DNA negative (with a cutoff value of $<300$ copies $/ \mathrm{mL}$ ) after 24 weeks off-therapy, it is likely that most patients would have detectable HBV DNA, if the follow-up was extended. Therefore, treatment for longer than 24 weeks would be needed to achieve the durable remission.

In accordance with the potent and sustained viral suppression, clevudine treatment led to a high frequency of serum ALT normalization at the end of the 24-week treatment and during the post-treatment follow-up. The proportion of patients with normal ALT tended to increase over time up to 10 weeks after treatment (week 34) in the clevudine group. The increase in the proportion of patients with normal ALT levels after cessation of therapy seems to reflect sustained viral suppression.

Clevudine was well tolerated, with no specific pattern of adverse events emerging during the study. The overall adverse event profile of the $30-\mathrm{mg}$ dose of clevudine was similar to that of placebo.

The potent suppression of viral replication associated with treatment with clevudine is expected to minimize the 
Table 4. Summary of Cumulative Safety Data

\begin{tabular}{lccc}
\hline & \multicolumn{2}{c}{$\begin{array}{c}\text { Number of Patients } \\
\text { (\%) }\end{array}$} & \\
\cline { 2 - 3 } & $\begin{array}{c}\text { Clevudine } \\
\text { (n }=\mathbf{6 3 )}\end{array}$ & $\begin{array}{c}\text { Placebo } \\
\text { (n= 23) }\end{array}$ & P value \\
\hline \multicolumn{1}{c}{ Timing and Event } & & & \\
\hline During treatment & 0 & 0 & \\
$\quad$ Discontinuation due to adverse event & $29(46.0)$ & $11(47.8)$ & $0.8826^{\dagger}$ \\
Any adverse event & $4(6.4)$ & $2(8.7)$ & $0.6561^{\ddagger}$ \\
Serious adverse event & $3(4.8)$ & $5(21.7)$ & $0.0292^{\ddagger}$ \\
ALT $\geq 5 \times$ ULN & $1(1.6)$ & $2(8.7)$ & $0.1731^{\ddagger}$ \\
Exacerbation of hepatitis B & & & \\
During treatment-free follow-up & $17(27.0)$ & $7(30.4)$ & $0.7522^{\dagger}$ \\
Any adverse event & $3(4.8)$ & $2(8.7)$ & $0.6066^{\ddagger}$ \\
Serious adverse event & $2(3.2)$ & $3(13.0)$ & $0.1163^{\ddagger}$ \\
ALT $\geq 5 \times$ ULN & & & \\
\hline
\end{tabular}

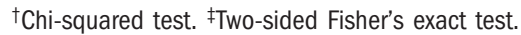

risk of development of resistant mutants. In this study, there was no evidence of emergence of drug resistance in clevudine-treated patients during the treatment period. However, the resistance profile of clevudine remains to be determined by longer-term resistance surveillance studies.

In summary, clevudine therapy for 24 weeks in e-CHB patients was safe, well-tolerated, and effective in producing highly potent and durable antiviral effect without emergence of drug resistance. Presumably, its potent and durable antiviral activity irrespective of baseline ALT levels may be a potentially important advantage in the treatment of $\mathrm{HBeAg-negative} \mathrm{patients,} \mathrm{most} \mathrm{of} \mathrm{whom} \mathrm{will}$ require long-term therapy. We propose that clevudine be considered as a primary therapy for nucleoside analognaive patients with e-CHB.

Acknowledgment: We acknowledge the contributions of the following Data Monitoring Committee Members: Jun Mo Jung, Kyungpook National University Hospital; Sei Jong Kim, Chonnam National University Hospital; Young Myung Moon, Yonsei University Hospital; Dong Jin Suh, Asan Medical Center; Chang Hong Lee, Konkuk University Hospital; and Kyu Won Chung, Ewha Womans University.

\section{References}

1. Hepatitis B: fact sheet WHO/204. Geneva: World Health Organization, October 2000. Available at: http://www.who.int/mediacentre/factsheets/ fs204/en. Last accessed: February 10, 2006.

2. Lavanchy D. Hepatitis B virus epidemiology, disease burden, treatment, and current and emerging prevention and control measures. J Viral Hepat 2004;11:97-107.

3. Hadziyannis SJ, Vassilopoulos D. Immunopathogenes of hepatitis B e antigen negative chronic hepatitis B injection. Antiviral Res 2001;52:9198.

4. Hadziyannis SJ, Vassilopoulos D. Hepatitis B e antigen-negative chronic hepatitis B. Hepatology 2001;34:617-624.

5. Funk ML, Rosenberg DM, Lok ASF. Worldwide epidemiology of HBeAgnegative chronic hepatitis $\mathrm{B}$ and associated precore and core promoter variants. J Viral Hepat 2002;9:52-61.
6. Chan HLY, Leung NWY, Hussain M, Wong ML, Lok ASF. Hepatitis B e antigen-negative chronic hepatitis B in Hong Kong. Hepatology 2000; 31:763-768.

7. Yoo BC, Park JW, Kim HJ, Lee DH, Cha YJ, Park SM. Precore and core promoter mutations of hepatitis $\mathrm{B}$ virus and hepatitis $\mathrm{B}$ e antigen-negative chronic hepatitis B in Korea. J Hepatol 2003;38:98-103.

8. Chu CJ, Hussain M, Lok ASF. Quantitative serum HBV DNA levels during different stages of chronic hepatitis B infection. Hepatology 2002;36:1408-1415.

9. Manesis EK, Papatheodoridis GV, Sevastianos V, Cholongitas E, Papaioannou C, Hadziyannis SJ. Significance of hepatitis B viremia levels determined by a quantitative polymerase chain reaction assay in patients with hepatitis B e antigen-negative chronic hepatitis B virus infection. Am J Gastroenterol 2003;98:2261-2267.

10. Papatheodoridis GV, Hadziyannis SJ. Current management of chronic hepatitis B. Aliment Pharmacol Ther 2004;19:25-37.

11. Brunetto MR, Oliveri F, Coco B, Leandro G, Colombatto P, Gorin JM, et al. Outcome of anti-HBe positive chronic hepatitis B in alpha-interferon treated and untreated patients: a long-term cohort study. J Hepatol 2002; 36:263-270.

12. Fattovich G. Natural history of hepatitis B. J Hepatol 2003;39(Suppl 1):S50-S58

13. Conjeevaram HS, Lok ASF. Management of chronic hepatitis B. J Hepatol 2003;38(Suppl 1):S90-S103. [Erratum: J Hepatol 2003;38:876.]

14. Rizzetto M, Tassopoulos NC, Goldin RD, Esteban R, Santantonio T, Heathcote EJ, et al. Extended lamivudine treatment in patients with HBeAg-negative chronic hepatitis B. J Hepatol 2005;42:173-179.

15. Papatheodoridis GV, Dimou E, Laras A, Papadimitropoulos V, Hadziyannis $S J$. Course of virologic breakthroughs under long-term lamivudine in HBeAg-negative precore mutant HBV liver disease. Hepatology 2002; 36:219-226.

16. Di Marco V, Marzano A, Lampertico P, Andreone P, Santantonio T, Almasio PL, et al. Clinical outcome of HBeAg-negative chronic hepatitis B in relation to virological response to lamivudine. Hepatology 2004; 40 : 883-891.

17. Liaw YF, Leung N, Guan R, Lau GK, Merican I, McCaughan G, et al. Asian-Pacific consensus statement on the management of chronic hepatitis B: a 2005 update. Liver Int 2005;25:472-489.

18. Keeffe EB, Dieterich DT, Han SH, Jacobson IM, Martin P, Schiff ER, et al. A treatment algorithm for the management of chronic hepatitis $B$ virus infection in the United States: an update. Clin Gastroenterol Hepatol 2006;4:936-962.

19. Lok AS, McMahon BJ. Chronic hepatitis B. Hepatology 2007;45:507539.

20. de Franchis R, Hadengue A, Lau G, Lavanchy D, Lok A, McIntyre N, et al. EASL International Consensus Conference on Hepatitis B. J Hepatol 2003;39(Suppl 1):S3-S25.

21. Marcellin P, Lau GKK, Bonino F, Farci P, Hadziyannis S, Jin R, et al. Peginterferon alfa- $2 \mathrm{a}$ alone, lamivudine alone, and the two in combination in patients with HBeAg-negative chronic hepatitis B. N Engl J Med 2004; 351:1206-1217.

22. Rizzetto M. Efficacy of lamivudine in HBeAg-negative chronic hepatitis B. J Med Virol 2002;66:435-451.

23. Hadziyannis SJ, Tassopoulos NC, Heathcote EJ, Chang TT, Kitis G, Rizzetto $\mathrm{M}$, et al. Adefovir dipivoxil for the treatment of hepatitis $\mathrm{B}$ e antigen-negative chronic hepatitis B. N Engl J Med 2003;348:800-807.

24. Hadziyannis SJ, Tassopoulos NC, Chang T-T, Heathcote EJ, Kitis G, Rizzetto M, et al. Long-term adefovir dipivoxil treatment induces regression of liver fibrosis in patients with $\mathrm{HBeAg}$-negative chronic hepatitis B: results after 5 years of therapy [Abstract]. HEPATOLOGY 2005;42(Suppl): 754A.

25. Lai CL, Shouval D, Lok AS, Chang TT, Cheinquer H, Goodman Z, et al. Entecavir versus lamivudine for Patients with $\mathrm{HBeAg}$-negative chronic hepatitis B. N Engl J Med 2006;354:1011-1020.

26. Colonno R, Rose R, Pokornowski K, Baldick C, Klesczewski K, Tenney D. Assessment at three years shows high barrier to resistance is maintained in entecavir treated nucleoside naive patients while resistance emergence in- 
creases over time in lamivudine-refractory patients [Abstract]. HEPATOLOGY 2006;44(Suppl):229A-230A.

27. Chu CK, Ma T, Shanmuganathan K, Wang C, Xiang Y, Pai SB, et al. Use of 2 -fluoro-5-methyl- $\beta$-L-arabinofuranosyluracil as a novel antiviral agent for hepatitis B virus and Epstein-Barr virus. Antimicrob Agents Chemother 1995;39:979-981.

28. Yao GQ, Liu SH, Chou E, Kukhanova M, Chu CK, Cheng YC. Inhibition of Epstein-Barr virus replication by a novel L-nucleoside, $2^{\prime}$-fluoro-5-methyl- $\beta$ L-arabinofuranosylurail. Biochem Pharmacol 1996;51:941-947.

29. Chin R, Shaw T, Torresi J, Earnest-Silveira L, Trautwein C, Bock T, et al. In vitro susceptibilities of wild-type and drug-resistant hepatitis $\mathrm{B}$ virus to (-)- $\beta$ D-2,6-diaminopurine dioxolane and 2'-fluoro-5-methyl- $\beta$-L-arabinofuranosyluracil. Antimicrob Agents Chemother 2001;45:2495-2501.

30. Pai SB, Liu SH, Zhu YL, Chu CK, Cheng YC. Inhibition of hepatitis B virus by a novel L-nucleoside, $2^{\prime}$-fluoro- 5 -methyl- $\beta$-L-arabinofuranosyluracil. Antimicrob Agents Chemother 1996;40:380-386.

31. Ma T, Pai SB, Zhu YL, Lin JS, Shanmuganathan K, Du J, et al. Structureactivity relationships of 1-(2-deoxy-2-fluoro- $\beta$-L-arabinofuranosyluracil) pyrimidine nucleosides as anti-hepatitis B virus agents. J Med Chem 1996 39:2835-2843.

32. Peek SF, Cote PJ, Jacob JR, Toshkov IA, Hornbuckle WE, Baldwin BH, et al. Antiviral activity of clevudine [L-FMAU, (1-(2-fluoro-5-methyl $\beta$-Larabinofuranosyl)uracil)] against woodchuck hepatitis virus and gene expression in chronically infected woodchucks (Marmota monax). Hepatology 2001;33:254-266.
33. Zhu Y, Yamamoto T, Cullen J, Saputelli J, Aldrich CE, Miller DS, et al. Kinetics of hepadnavirus loss from the liver during inhibition of viral DNA synthesis. J Virol 2001;75:311-322.

34. Summers J, Mason WS. Residual integrated viral DNA after hepadnavirus clearance by nucleoside analog therapy. Proc Natl Acad Sci U S A 2004;101: 638-640.

35. Marcellin P, Mommeja-Marin H, Sacks SL, Lau GKK, Sereni D, Bronowicki JP, et al. A phase II dose escalating trial of clevudine in patients with chronic hepatitis B. Hepatology 2004; 40:140-148.

36. Lee HS, Chung YH, Lee KS, Byun KS, Paik SW, Han JY, et al. A 12-week clevudine therapy showed potent and durable antiviral activity in $\mathrm{HBeAg}$ positive chronic hepatitis B. Hepatology 2006;43:982-988.

37. Yoo BC, Kim JH, Lee KS, Kim TH, Paik SW, Ryu SH, et al. A 24-week clevudine monotherapy produced profound on-treatment viral suppression as well as sustained viral suppression and normalization of aminotransferase levels for 24 weeks off-treatment in $\mathrm{HBeAg}(+)$ chronic hepatitis B patients [Abstract]. Hepatology 2005;42(Suppl):270A-271A.

38. Perrillo RP, Lai CL, Liaw YF, Dienstag JL, Schiff ER, Schalm SW, et al. Predictors of $\mathrm{HBeAg}$ loss after lamivudine treatment for chronic hepatitis B. Hepatology 2002;36:186-194.

39. Santantonio T, Mazzola M, Iacovazzi T, Miglietta A, Guastadisegni A, Pastore G. Long-term follow-up of patients with anti-HBe/HBV DNApositive chronic hepatitis $B$ treated for 12 months with lamivudine. J Hepatol 2000;32:300-306. 